\title{
Economic Conditions And How It Effects Trade Between The U.S. And India
}

\author{
Michael J. Bosloper, (Email: BosloperM@wpunj.edu), William Paterson University \\ Angela Castellano, (Email: CastellanoA@wpunj.edu), William Paterson University \\ Ruthann M. England, (Email: EnglandR@wpunj.edu), William Paterson University \\ Dinh Galdi, (Email: GaldiD@wpunj.edu), William Paterson University \\ Tricia C. Snyder, (Email: Snydert@wpunj.edu), William Paterson University
}

\begin{abstract}
This paper examines the economic conditions that effect trade between the U.S. and India. Examining the existing economic conditions of both countries is important to determine the current and future trade issues that both countries may face. Since India's formation in 1947 and up until 1991, India was a closed economy with strict controls and regulations regarding trade. After a severe economic crisis in 1991 India started opening its borders to foreign trade, embraced globalization and drastically liberalized its trade policy. However, the exploding population in India is having strong economic and environmental implications for India and how it relates to the rest of the world.
\end{abstract}

\section{INTRODUCTION}



he world Economy is a complex machine. Economists use many tools to help determine what course of action needs to be taken to improve economic conditions. Our report examines the economic conditions that effect trade between two nations: the United States, a major player in the global economy and India, a third world nation aspiring to be a world player.

Examining the existing economic conditions of both nations is important to determine future trade issues and can be seen in Table 1. India has a real GDP economic growth rate of $8.3 \%$, which is relatively high to that of the U.S. with an economic growth rate of 3.1\%. The GDP per capita for India is $\$ 2,900$ which is relatively small compared to that of the U.S. $\$ 37,800$. The GDP per capita is so much higher for the U.S. because our population is about 5 times lower than that of India. The unemployment rate is $9.5 \%$, which is extremely high.

Table 1

\begin{tabular}{|l|c|c|}
\hline & India & United States \\
\hline Economic Growth & 8.3 & 3.1 \\
\hline Per Capita GDP & $\$ 2900$ & $\$ 37,800$ \\
\hline Inflation & $3.8 \%$ & $2.3 \%$ \\
\hline Unemployment & $9.5 \%$ & $5.8 \%$ \\
\hline Population & $1,065,070,607$ & $293,027,571$ \\
\hline Trade Balance & $59.7 \%$ & $64.4 \%$ \\
\hline Exchange Rates & 46.5806 Rupees & $1 \$$ \\
\hline Interest Rates & $.25 \%$ & $5.75 \%$ \\
\hline
\end{tabular}

The high unemployment rate is correlated to the high population and lead to the increasing high poverty in India. The population must become controlled in order to move this country forward into better economic times. India is second in population only to China. India's population is $1,065,070,607$. In comparison, the U.S. population 
is only 293,027,571. In order for India to become a developed country they must reduce their population significantly.

An exploding population in urban India is causing massive environmental decay. Large-scale industrialization, increasing vehicle usage, and an increasing strain on the infrastructure have added to the difficulty of maintaining a healthy natural resource base and a clean environment. For example, New Delhi is now considered the fourth most polluted city in the world, where airborne particulate matter (PM) has been recorded at levels more than 10 times India's legal limit. The major cause of increased air pollution in urbanized areas is blamed on increased vehicle ownership. With the rise of income in these areas and automobiles becoming more and more affordable, personal vehicle ownership is on the rise. Recognizing that emissions from vehicles are becoming a serious problem, India has passed legislation that prohibits vehicles older than 15 years from driving on the roads. India's environmental issues remain a top priority for the government. Some of its issues may be associated with the lack of economic growth, while others stem from the expanding economic activity. Environmental decay can be traced to several direct causes, including economic growth, population growth, urbanization, rising energy use and transportation. However, poverty remains at the root of several environmental problems.

A rising population also creates a strain on energy production. Therefore, new plants and increased productivity at energy plants are always under consideration. Coal burning plants account for over 50\% of India's energy consumption, followed by petroleum (34\%), natural gas (6.5\%), hydroelectricity $(6.3 \%)$, nuclear (1.7\%), and geothermal, wind, solar and biomass making up the smallest percentage (.2\%). Of new plants created, the most cost effective for India at this time are coal powered plants, of which emissions are the worst. The tremendous pressure on the power grid, due to the population size, makes blackouts a widespread problem across the country, disrupting daily life for many citizens.

Roughly $70 \%$ of India's population still resides in rural areas, and this section of society is plagued by under development and deteriorating economic growth. Among the environmental problems this segment of society faces is inadequate sanitation, minimal access to clean drinking water, as well as little to no electricity. With no infrastructure and no access to electricity, it is almost impossible to expect this segment of society to advance to satisfactory levels of environmental standards.

Since India's founding in 1947 and up until 1991, India was a closed economy with strict controls and regulations of imports and exports, and with high tariffs and quantitative restrictions. After a severe economic crisis in 1991 India started opening its borders to foreign trade, embraced globalization and drastically liberalized its trade policy.

U.S. trade with India has been on the rise since 1991. The increase in India's trade with the United States can be seen on Table 2 and Figures 1 and 2, which show that imports from India have on average increased from 1999-2004. In addition, the U.S. has had a negative trade balance with India in that period. Currently the U.S. trade deficit with India is $-\$ 7,171.20$ million of U.S. dollars.

Table 2 - The U.S. Trade Balance With India: 1999-2004

\begin{tabular}{|c|c|c|c|}
\hline Year & Exports & Imports & Trade Balance \\
\hline 1999 & $3,687.80$ & $9,070.80$ & $-5,383.00$ \\
\hline 2000 & $3,667.30$ & $10,686.60$ & $-7,019.30$ \\
\hline 2001 & $3,757.00$ & $9,737.30$ & $-5,980.30$ \\
\hline 2002 & $4,101.00$ & $11,818.40$ & $-7,717.40$ \\
\hline 2003 & $4,979.70$ & $13,055.30$ & $-8,075.60$ \\
\hline 2004 & $4,369.00$ & $11,540.30$ & $-7,171.20$ \\
\hline
\end{tabular}

*Note: All figures are in millions of U.S. Dollars. 
Figure 1 - U.S. Trade With India: 1999-2004



While India is not listed on the top 15 trading partners for the U.S. and accounts for only about $1 \%$ of all U.S. trade, the United States is India's largest trading partner. The U.S. accounts for $11.6 \%$ of India's total share of trade in 2003-2004, as reflected in Table 3. India's second largest trading partner in 2002-03 was the United Kingdom and Belgium, however in the period 2003-04, United Arab Emirates (UAE) followed by China were their 2nd and $3^{\text {rd }}$ biggest trading partners.

Table 3 - India's Major Trading Partners

\begin{tabular}{|l|c|c|c|c|}
\hline \multicolumn{5}{|c|}{ (\% Share In The Total Trade) } \\
\hline Country & $\mathbf{2 0 0 0 - 0 1}$ & $\mathbf{2 0 0 1 - 0 2}$ & $\mathbf{2 0 0 2 - 0 3}$ & $\mathbf{2 0 0 3 - 0 4}$ \\
\hline 1. U.S.A. & 13 & 12.2 & 13.4 & 11.6 \\
\hline 2. UK & 5.7 & 5 & 4.6 & 4.4 \\
\hline 3. Belgium & 4.6 & 4.4 & 4.7 & 4.1 \\
\hline 4. Germany & 3.9 & 4 & 4 & 3.9 \\
\hline 5. Japan & 3.8 & 3.8 & 3.2 & 3.1 \\
\hline 6. Switzerland & 3.8 & 3.4 & 2.4 & 2.7 \\
\hline 7.Hong Kong & 3.7 & 3.2 & 3.1 & 3.4 \\
\hline 8. UAE & 3.4 & 3.6 & 3.8 & 5 \\
\hline 9. China & 2.5 & 3.1 & 4.2 & 4.9 \\
\hline 10. Singapore & 2.5 & 2.4 & 2.5 & 2.9 \\
\hline 11. Malaysia & 1.9 & 2 & 1.9 & 2.1 \\
\hline
\end{tabular}


Figure 2 - U.S. Trade Balance with India

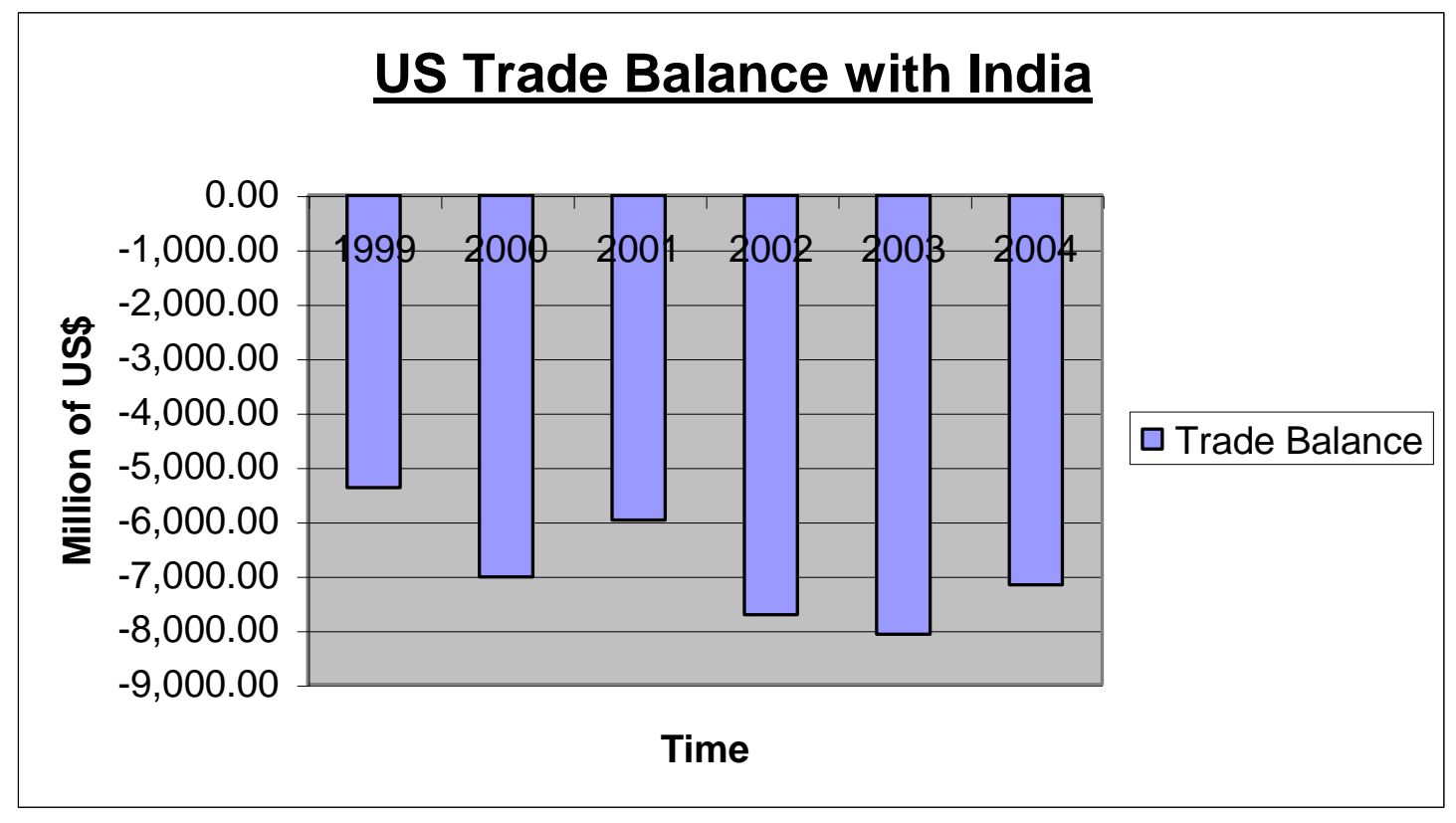

Due to its population size, India has comparative advantages in labor-intensive products. More specifically, India's comparative advantage are seen in their main exports, which include gems and jewelry, cotton yarns and fabrics, drugs, pharmaceuticals and fine chemicals, plastic and linoleum products man made fibers and processed minerals to name a few. India imports raw materials such as petroleum crude and products, electronic goods, and precious and semiprecious stones and then uses these materials to create such things as jewelry, which is then exported. In fact, the U.S. and China are India's main sources of imports. The percentage share of imports coming into India from the U.S. is $6.31 \%$.

While the U.S. is currently India's biggest trade partner, this may change as India increases its trade alliances with other countries. Despite India's inward orientation and economic policies prior to 1991, India was one of the founding members of the GATT (General Agreement on Trade and Tariffs - signed 1947). Later, India was also a founding member of the WTO and is a member to several WTO Agreements that regulate different issues of international trade. These include the WTO Multilateral Agreement on Trade in Goods (with special Agreements on Agriculture, Antidumping, Customs, Import Licensing, Information Technology, Pre-shipment Inspection, Textiles and Clothing, and Technical Barriers). Other WTO Agreements include General Agreement on Trade in Services; Understanding on Commitments in Financial Services; and Understanding on Settlement of Disputes.

Although India has preferred being a member of global trade agreements, it has also signed a number of important Regional Trade Agreements (RTA), both with its neighbors and with non-neighbor major trading partners. These are preferential trade agreements aimed at enhancing economic cooperation and trade, by either significantly reducing or completely eliminating tariffs on selected goods and service and encouraging free flow of investments.

One of the most important regional agreements that India is part of is the South Asian Association for Regional Cooperation (SAARC). In 1995 the members of SAARC signed the SAARC Preferential Trading Agreement (SAPTA). For now SAPTA members enjoy broad tariff concessions, but the ultimate goal is to create the South Asian Free Trade Area, within one to two decades, removing all tariff and non-tariff barriers to trade. This would be the only regional organization of which India will be a member and which aims for total elimination of all trade barriers with the goal to establish completely free flow of goods, services and investment capital. 
Currently, India is actively working on joining the Association of South East Asian Nations (ASEAN) which is one of the most important economic and political organizations in the region. A significant step for India occurred in August 2003, with the signing of the Framework Agreement on Comprehensive Economic Cooperation between the Association of South East Asian Nations (ASEAN) and India. This agreement provides a plan for a gradual elimination of tariffs and free trade on selected goods (mostly manufacturing and to some extent agriculture).

A third very important regional trade agreement is the India - MERCOSUR Preferential Trade Agreement. The initial Framework Agreement was signed in 2003, and provides for reciprocal trade concessions. In January 2004 a Preferential Trade Agreement (PTA) was signed, which not only strengthened the existing relations but pointed out the possible formation of a completely free trade zone in the future.

India is also a member of the Bangkok Agreement that was first signed in 1975, and today comprises Bangladesh, Republic of Korea, the Lao People's Democratic Republic, Papua New Guinea and Sri Lanka. The Bangkok Agreement provides for tariff concessions on selected goods. The Bangkok Agreement has lost some of its importance sense many of the nations in this Agreement have similar and more far reaching agreements, either through one of the above mentioned regional organizations, or due to direct bilateral agreements between India and some of the members of the Bangkok Agreement.

Important bilateral trade agreements include: India - Sri Lanka, India - Thailand, India - Singapore, India Japan, and India - Korea. These agreements mainly emphasize trade liberalization, simplification of trade rules and economic cooperation in general.

Before the 1991 trade liberalization period, India's policy of protectionism relied heavily on tariffs, quantitative restrictions (quotas) and import prohibitions both to protect domestic industry and as a major source of revenues. For the years of 2001 and 2002 tariffs amounted to almost $30 \%$ of net tax revenue.

In the 1990's, during the time of trade liberalization, India introduced numerous reforms directed at overhauling and opening its economy. Under the WTO Agreements India successfully remove all its quantitative restrictions (i.e. quotas) on almost all the goods. A final round of reforms occurred in 2001, which discarded all the quotas.

Another major change was in tariffs. After signing the WTO agreements India started by placing a so-called bound, i.e. ceiling, on its tariffs. These bounds (ceilings) only impose the upper limit of how high a tariff can be. These bound tariffs usually serve to allow for a smooth transition from a highly regulated high tariff environment to a more liberal environment. By imposing bounds only, the country still has a lot of liberty in deciding actual tariffs to be applied. From 1994 to 2001 these tariffs have constantly been revised downward, i.e. decreased. Tariffs were completely eliminated on all intermediate industrial goods that are used in India's industry to produce final products for export.

However high tariffs remain today on all agricultural products, with the current average tariff rate of $41.7 \%$ (with a bound of $115 \%$ - meaning India can increase agricultural tariffs to $115 \%$ if it chooses to do so). Current applied tariffs for specific foods like edible oils tariff is $56 \%$, and for beverages and spirits the rate is $96.9 \%$. On nonagricultural products the tariffs have been steadily declining and today they average $31.1 \%$. Among these goods that remain highly protected are transportation equipment, with the average rate of $40 \%$, textiles and clothing industry, $31 \%$; and chemical industry, $34 \%$.

Although the tariffs have declined, there is a new disturbing trend to impose "surcharge duties", which are basically additional duties that an importers needs to pay to the government of India. These duties can be up to 15\% and are especially directed towards finished consumer products. This strategy indicates India's willingness to open its borders to raw materials and intermediate manufacturing products, however, tightly regulates the import of consumer products. 
Currently there are no sanctions imposed on India. However, sanctions were imposed on India 1998 by the U.S., at which time India failed to comply with the Nuclear Nonproliferation Treaty, and instead tested its nuclear weapons. These sanctions included sanctions on all arms deals and military cooperation, and sanctions on foreign aid and financial support and credit guarantees. These sanctions were overturned in 2001.

Although there are no more sanctions and embargoes, there are still several categories of goods that cannot be exported from the U.S. to India. This policy is administered by the Bureau of Export Administration within the U.S. Department of Commerce. These U.S. imposed export controls are for goods and technical data for reasons of national security, chemical/biological weapons, nuclear weapons, missile technology and high - tech equipment that is categorized as the "dual - use" technology, i.e. that can be used both in military and civilian applications.

India has asked that the United States be investigated for antidumping in the textile market. India claimed that the U.S. rules of origin improperly differentiated between textile, apparel and other industrial products. Another charge that India leveled against the U.S. was that the U.S. rules were only adopted to protect the U.S. textile industry from competition. The third charge, which India argued was the rule of origin, distorted, disrupted and restricted international trade. The final argument that India had was that the U.S. rules were administered in a discriminatory manner. The WTO rejected all of India's challenges in the textile case of June 20, 2003.

The U.S. challenges India on antidumping and countervailing duty laws February 10, 2000. The U.S. began an investigation into India's steel plate because the company failed to provide the necessary information. The information provided from India's respondent company was unusable, so the U.S. used the facts available provisions to calculate an antidumping margin for the company during the investigation. Next the U.S. imposed an antidumping order on Indian steel plate imports due to the information it had received. India challenged the imposed order to the WTO but the WTO upheld the U.S. order saying that due to the facts available, the practice and measure that the U.S. acted consistently with the developing country provision of the antidumping agreement. This ruling came July 24 , 2001 and issued the final report June 21, 2002.

\section{CONCLUSION}

In conclusion, India faces numerous challenges in order to improve the economic conditions of the country. In order to become a major player in world trade, India must significantly reduce their population growth rate and accelerate the reform process to sustain the 7-8\% growth rate over the next five years. If this growth rate is achieved, poverty will be drastically reduced. Although poverty has been reduced significantly to date, it still remains a major hurdle in their economic progress. Infrastructure remains another critical issue that needs to be addressed, particularly in transportation and energy. Funding for such facilities as ports, railroads, and telecommunications needs to be increased in order to improve quality and quantity. Without proper infrastructure, it will be difficult for India's growth to progress.

Further growth in world trade depends on India's ability to simplify its import and export regulations. Although India still has relatively high levels of protection under tariffs, tariff reductions in the service industry have proven to be a success. India's industry will greatly benefit if they reduce and align the customs duty rate to that of ASEAN countries. This will allow free trade to flourish among the ASEAN members.

Similar to the U.S., India's trade deficit is high and must be addressed as it continues to grow despite efforts reduce it. A way for India to tackle its deficit is to have a stronger currency, lower tariffs and softer interest rates, which will allow for an increase consumption and investment.

\section{REFERENCES}

1. India Review. (2004). CountryWatch Review, available online at http://www.countrywatch.com.

2. India: Trade Policy Review. (2002). The Secretariat's Report, WTO Secretariat, available online at http://www.wto.org. 
3. India: List of Agreements. Trade Compliance Center, U.S. Department of Commerce, available online at http://www.tcc.mac.doc.gov.

4. India: Customs Information: Tariffs, Non - Tariff Barriers, and Taxes. Trade Information Center, U.S. Department of Commerce, available online at http://web.ita.doc.gov.

5. India Sanctions. Office of the Press Secretary, The White House (1998), available online at http://www.mac.doc.gov/India/wh-state.htm.

6. India's Current Engagement in RTAs. (2004). Ministry of Commerce, Government of India, available online at http://commerce.nic.in/india_rta_main.htm.

7. Robb, Peter. (2002). A History of India. New York: Palgrave Essential Histories.

8. Wolpert, Stanley. (1999). India. Los Angles: University of California Press.

\section{NOTES}


International Business \& Economics Research Journal - March 2006

Volume 5, Number 3

\section{NOTES}

